Marquette University

e-Publications@Marquette

School of Dentistry Faculty Research and

Publications

Dentistry, School of

$1-2017$

\title{
Complete Mouth Rehabilitation and Gastroesophageal Reflux Disease: Conventional and Contemporary Treatment Approaches
}

Vasilios Chronopoulos

University of Athens

Georgios Maroulakos

Marquette University, georgios.maroulakos@marquette.edu

Konstantinos Tsoutis

University of Athens

Panagiota Stathopoulou

University of Pennsylvania

William W. Nagy

Texas A\&M Health Science Center

Follow this and additional works at: https://epublications.marquette.edu/dentistry_fac

Part of the Dentistry Commons

\section{Recommended Citation}

Chronopoulos, Vasilios; Maroulakos, Georgios; Tsoutis, Konstantinos; Stathopoulou, Panagiota; and Nagy, William W., "Complete Mouth Rehabilitation and Gastroesophageal Reflux Disease: Conventional and Contemporary Treatment Approaches" (2017). School of Dentistry Faculty Research and Publications.

173.

https://epublications.marquette.edu/dentistry_fac/173 


\title{
Complete Mouth Rehabilitation and Gastroesophageal Reflux Disease: Conventional and Contemporary Treatment Approaches
}

\author{
Vasilios Chronopoulos \\ Department of Prosthodontics, National and Kapodistrian \\ University of Athens, School of Dentistry, \\ Athens, Greece \\ Georgios Maroulakos \\ School of Dentistry, Department of General Dental Sciences, \\ Marquette University, \\ Milwaukee, WI \\ Konstantinos Tsoutis \\ Department of Prosthodontics, National and Kapodistrian \\ University of Athens, School of Dentistry, \\ Athens, Greece \\ Panagiota Stathopoulou \\ Department of Periodontics, University of Pennsylvania, \\ School of Dental Medicine, \\ Philadelphia, PA
}




\title{
William W. Nagy \\ Department of Restorative Sciences, Texas A\&M University, Baylor College of Dentistry, Dallas, $T X$
}

\begin{abstract}
This report describes the diagnosis and prosthodontic management of 2 patients with a history of chronic gastroesophageal reflux disease and worn dentition. Different treatment approaches were used for oral rehabilitation. Use of conventional and contemporary restorative materials resulted in functional and esthetic prosthodontic rehabilitation with a favorable prognosis.

Gastroesophageal reflux disease (GERD) is a "condition which develops when the reflux of stomach contents causes troublesome symptoms and/or complications. ${ }^{11}$ Reflux episodes can be intensified by dietary habits, smoking, physical exercise, and obstructive sleep apnea. ${ }^{1,2}$ and 3 Complications of GERD are regurgitation, chest pain, esophagitis, Barrett's esophagus, esophageal adenocarcinoma, cough, asthma, and dental erosion. ${ }^{1,4}$ and 5 GERD is associated with dental erosion and sleep bruxism, ${ }^{6}$ and 7 and dental erosion may be the only symptom of GERD. ${ }^{8}$
\end{abstract}

The purpose of this report was to present the oral diagnosis and management of 2 patients with chronic GERD who presented with tooth wear and required complete mouth rehabilitation. The restoration of dentition was achieved by following different treatment modalities.

\section{Clinical Report}

\section{Patient 1}

A 47-year-old woman presented complaining that her "teeth have worn out over time." Her medical history included mild chronic GERD, controlled with diet. Clinical and radiographic examinations revealed multiple root canal treatments (RCTs), amalgam restorations, 
NOT THE PUBLISHED VERSION; this is the author's final, peer-reviewed manuscript. The published version may be accessed by following the link in the citation at the bottom of the page.

and metal ceramic (MC) restorations (Fig. 1). Her last dental appointment was 2 months before the prosthodontic evaluation for extraction of the mandibular right first molar (Fig. 2). The patient underwent monitored occlusal device therapy before any treatment.
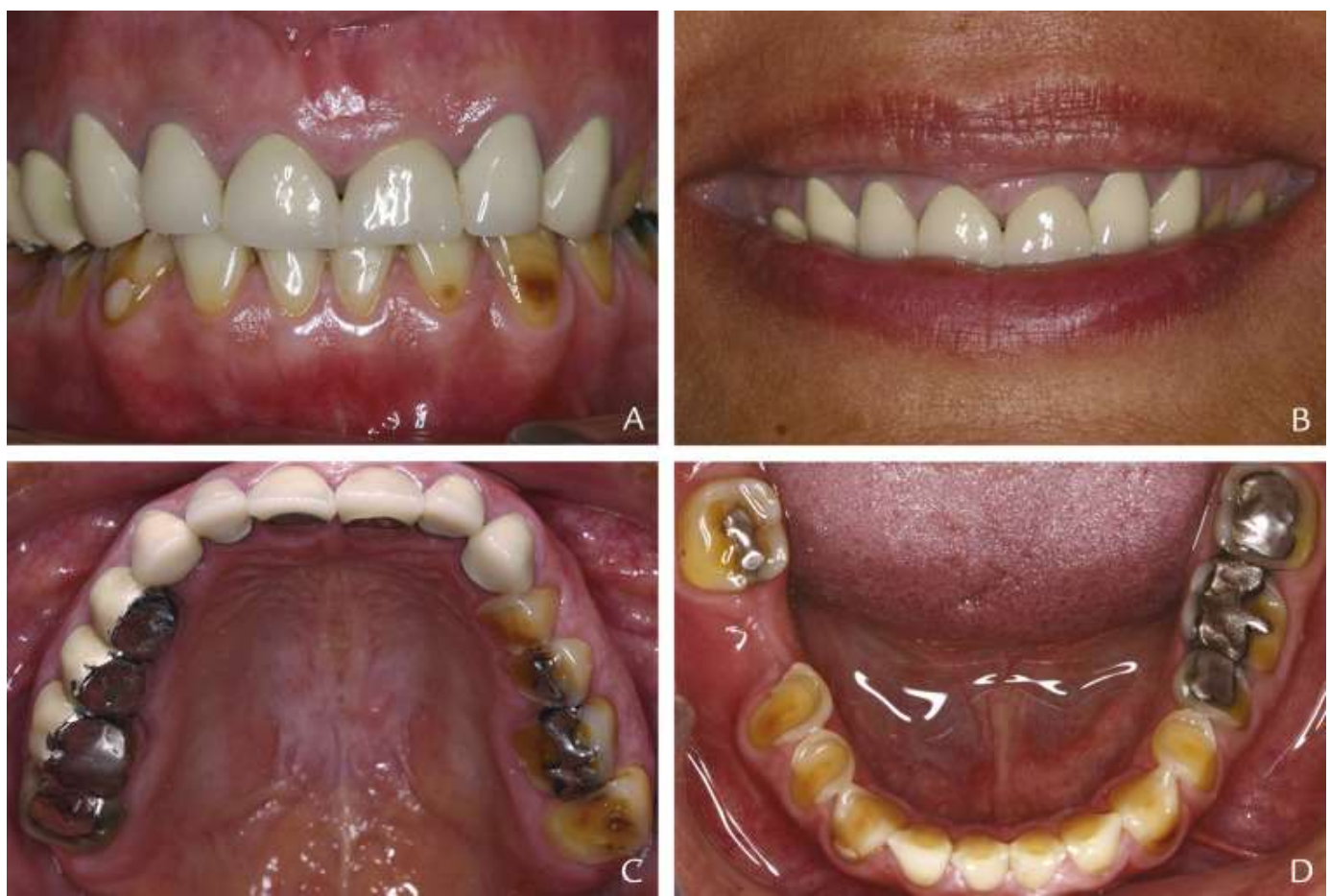

Figure 1. Patient 1 pretreatment. A, Maximum intercuspation position frontal view. B, Exaggerated smile. Note nonideal gingival display. C, Maxillary occlusal view. Note condition of existing restorations. D, Mandibular occlusal view. Note ridge defect at post extraction site of mandibular right first molar and formation of amalgam islands on left posterior teeth.

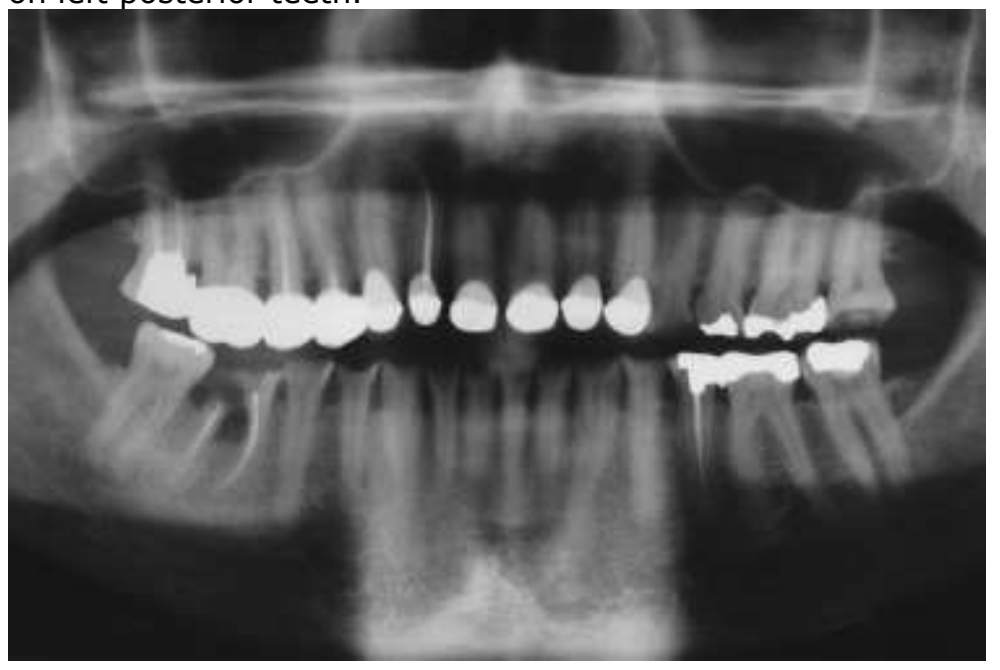

Figure 2. Panoramic radiograph, pretreatment.

Journal of Prosthetic Dentistry, Vol 117, No. 1 (January 2017): pg. 1-7. DOI. This article is (c) Elsevier and permission has been granted for this version to appear in e-Publications@Marquette. Elsevier does not grant permission for this article to be further copied/distributed or hosted elsewhere without the express permission from Elsevier. 
Diagnostic casts were obtained and mounted (Denar Mark II; Whip Mix Corp) using a facebow (Denar Slidematic; Whip Mix Corp) and centric relation records. The occlusal vertical dimension was evaluated, and a 3-mm increase was determined to allow adequate restorative space. A diagnostic waxing was used to evaluate esthetics and function and to fabricate interim prostheses (Fig. 3).
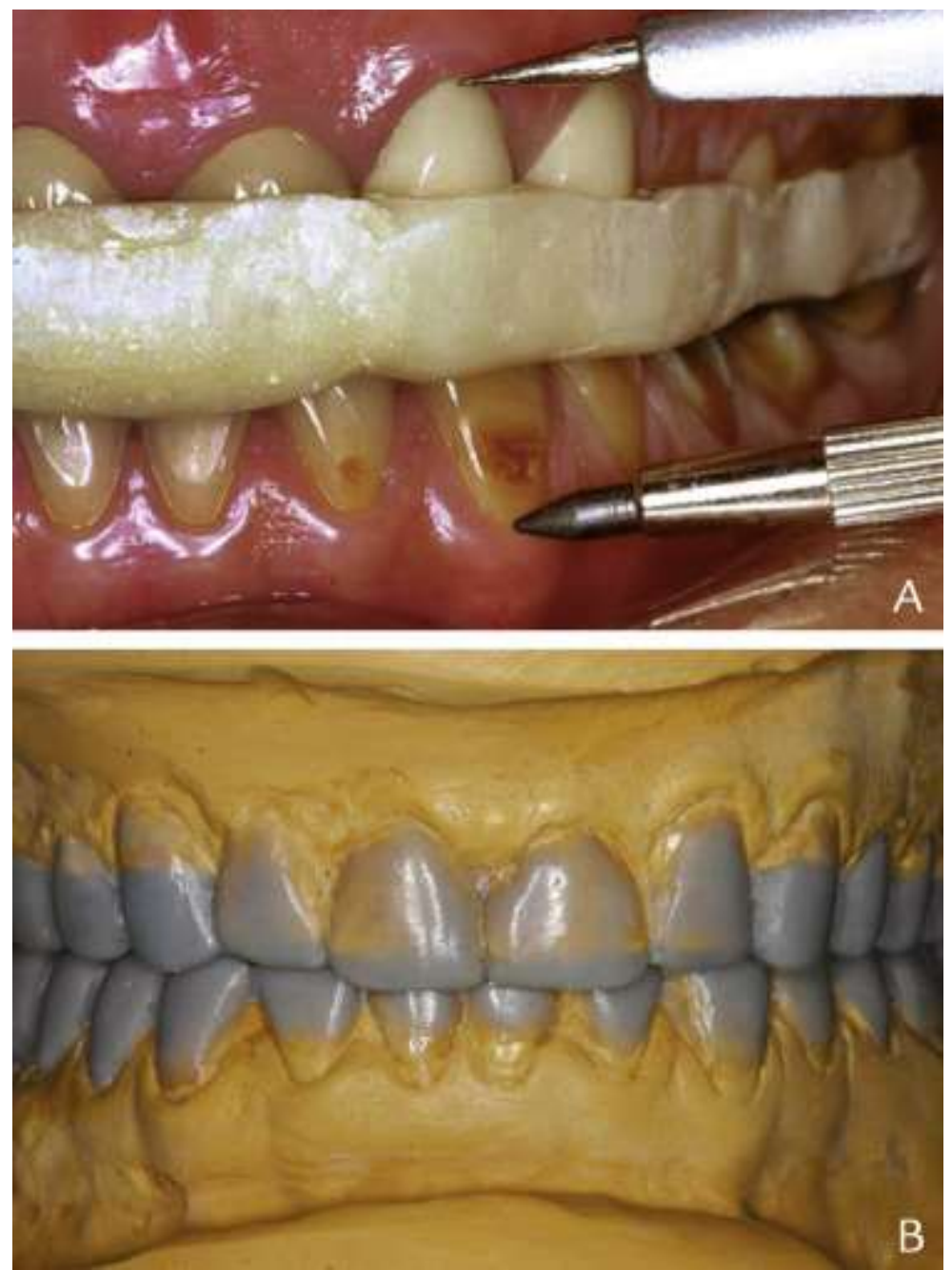

Figure 3. A, Occlusal vertical dimension evaluated with gingival height of left canines as reference. Monitored splint therapy was executed at proposed occlusal vertical dimension to locate musculoskeletally stable treatment position and evaluate patient's adaptation to new vertical dimension. B, Diagnostic waxing at proposed occlusal vertical dimension.

The problems identified were moderate to severe dental wear, defective restorations, inadequate tooth structure on several maxillary and mandibular teeth, inadequate anterior guidance, nonideal gingival 
display in an exaggerated smile, loss of attached mucosa, and presence of a mandibular right bone defect (Fig. 1). The definitive diagnosis included worn dentition caused primarily by erosion ${ }^{9,10,}$ 11 and 12 and occlusal instability. Her caries risk was low. ${ }^{13}$ The patient was characterized as category 2 relative to the occlusal vertical dimension associated with a treatment plan ${ }^{14}$ and as prosthodontic diagnostic index (PDI) class IV for partial edentulism. ${ }^{15}$ The treatment objectives were to control GERD, to maintain periodontal and dental health, and to provide functional and esthetic restorations. Significant treatment modifiers were the GERD and finances. The patient declined bone/soft tissue augmentation and implant placement.

The inadequate tooth structure was managed by crown lengthening and/or cast post and cores after RCT. The maxillary central incisors were lengthened to improve gingival architecture. Strip perforation at the mesiobuccal canal of the mandibular left first molar occurred during RCT. After evaluating the tooth, resection of the mesial root was proposed, ${ }^{16}$ as the patient refused extraction and implant placement (Fig. 4). The occlusal scheme established with the interim prostheses was mutually protected articulation. The patient was monitored for 4 months to evaluate esthetics, function, oral hygiene, and soft tissue healing. Definitive impressions were made with custom trays and polyvinyl siloxane material (Aquasil Ultra; Dentsply Intl). Casts of interim prostheses were made to facilitate cross mounting of definitive casts and to fabricate a custom incisal guide table. ${ }^{17}$ The interim prostheses were used to communicate the established esthetics (incisal edge position, contours, occlusal plane) and function (occlusal scheme, envelope of function, palatal contours of maxillary anterior teeth). The patient received MC fixed dental prostheses (FDPs) on all maxillary and mandibular teeth. All prostheses were cemented with resin-modified glass ionomer cement (Fuji Plus; GC Corp). 
NOT THE PUBLISHED VERSION; this is the author's final, peer-reviewed manuscript. The published version may be accessed by following the link in the citation at the bottom of the page.
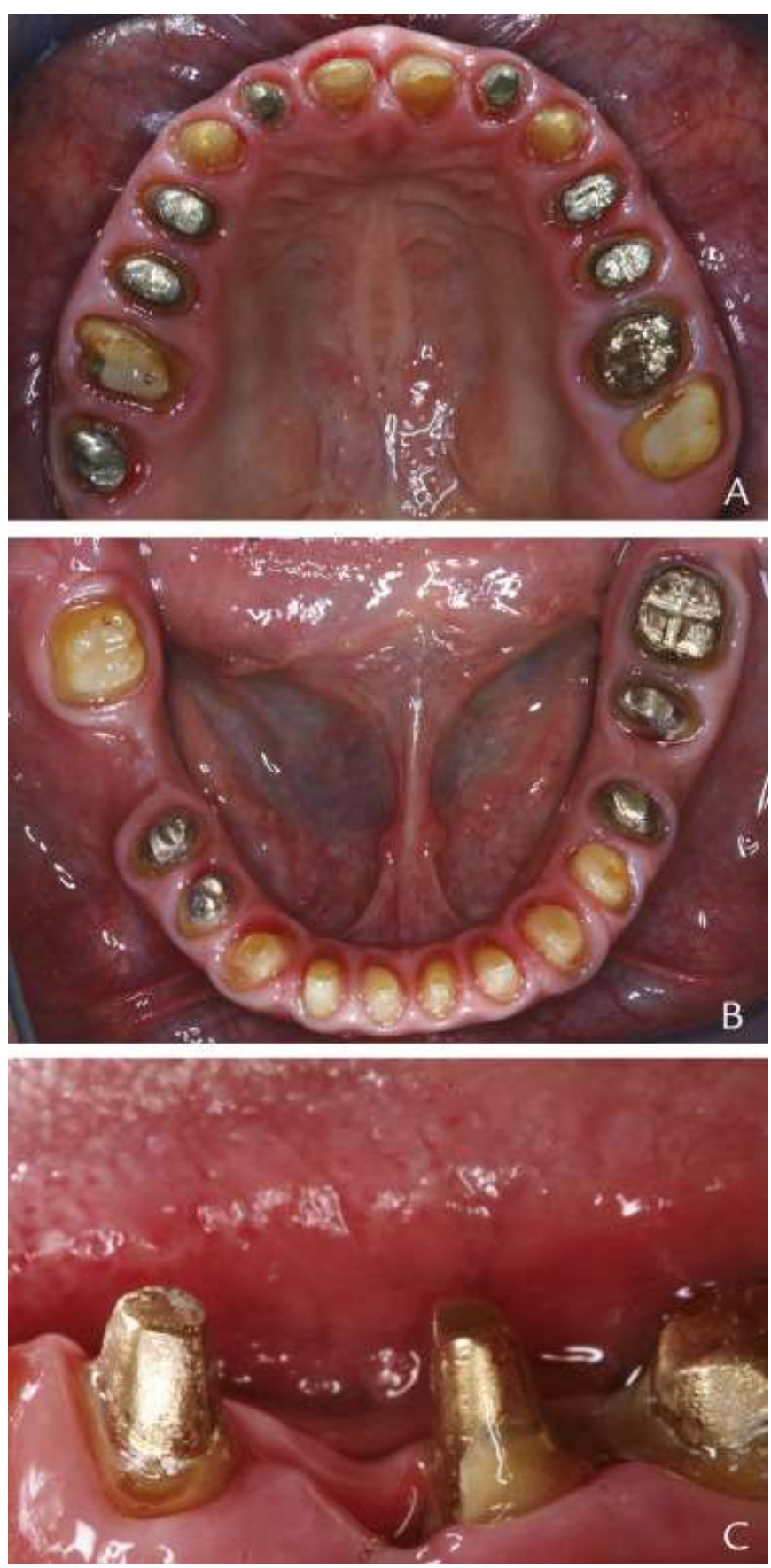

Figure 4. Tooth preparations. A, Maxillary. B, Mandibular. C, Cemented cast post/core on root-resected mandibular left first molar.

The patient received follow-up examination 1 week after insertion and was excited with her rehabilitation. A maxillary occlusal device was fabricated to protect the prostheses. The patient entered a 6-month recall maintenance program with favorable long-term

Journal of Prosthetic Dentistry, Vol 117, No. 1 (January 2017): pg. 1-7. DOI. This article is (C Elsevier and permission has been granted for this version to appear in e-Publications@Marquette. Elsevier does not grant permission for this article to be further copied/distributed or hosted elsewhere without the express permission from Elsevier. 
prognosis. After 3 years, she was still satisfied with her prostheses (Fig. 5).
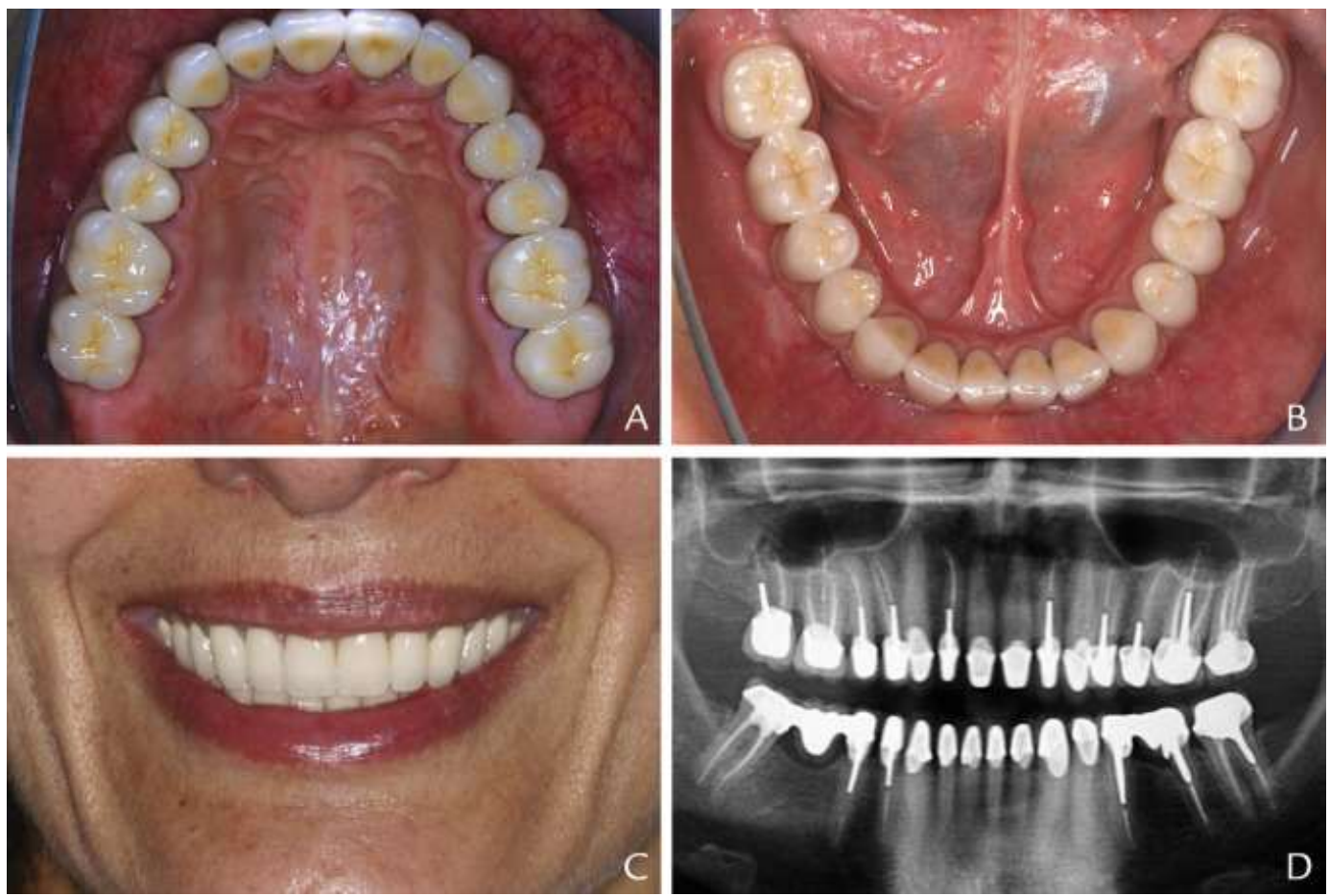

Figure 5. Patient 1 . Inserted definitive prostheses. A, B, Occlusal views. C, Exaggerated smile. D, Panoramic radiograph 3 years after insertion.

\section{Patient 2}

A 42-year-old woman complained of her "short and ugly teeth." Her medical history included chronic GERD, controlled with a histamine- 2 receptor antagonist. The patient had high esthetic expectations. Clinical and radiographic examination revealed existing RCTs, composite resin restorations, and MC restorations (Figs. 6, 7). The temporomandibular joint examination revealed clicking sounds on both joints but a normal range of motion and no pain. The patient admitted nocturnal bruxism. An occlusal device was fabricated and monitored for 6 weeks to allow the condyles to assume a stable treatment position. ${ }^{18}$ Diagnostic casts were mounted (Denar Mark II; Whip Mix Corp) using a facebow (Denar Slidematic; Whip Mix Corp) and centric relation records. The occlusal vertical dimension was evaluated, and an increase of $1 \mathrm{~mm}$ was determined to allow space for the restorative materials. Dual-polymerizing composite resin 
NOT THE PUBLISHED VERSION; this is the author's final, peer-reviewed manuscript. The published version may be accessed by following the link in the citation at the bottom of the page.

(Integrity; Dentsply Intl) was used as a trial restoration to evaluate the diagnostic waxing intraorally (Fig. 8).
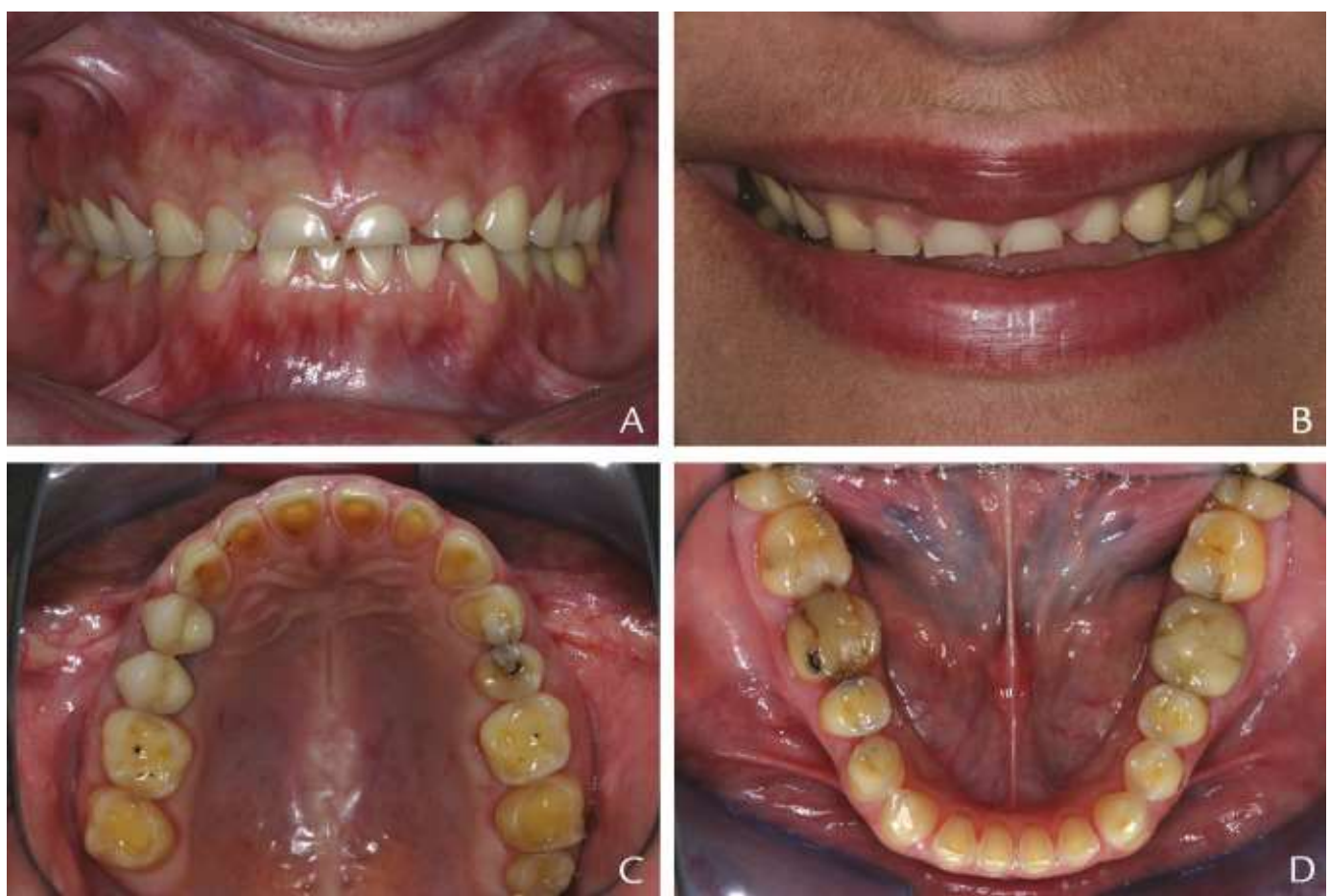

Figure 6. Patient 2 pretreatment. A, Maximum intercuspation position frontal view. B, Exaggerated smile. C, D, Occlusal views.

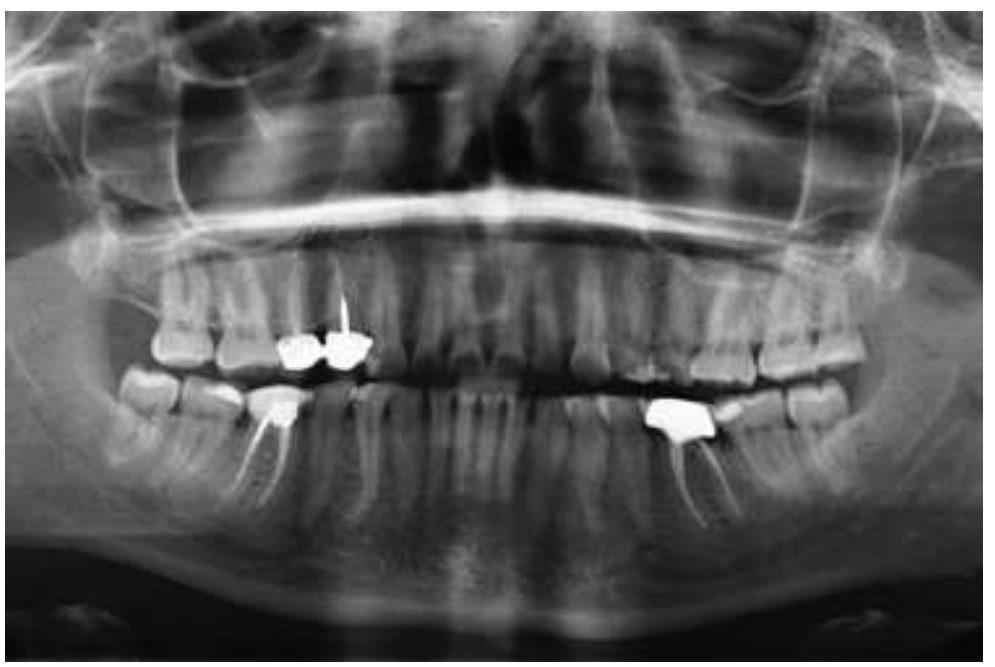

Figure 7. Panoramic radiograph, pretreatment.

Journal of Prosthetic Dentistry, Vol 117, No. 1 (January 2017): pg. 1-7. DOI. This article is (c) Elsevier and permission has been granted for this version to appear in e-Publications@Marquette. Elsevier does not grant permission for this article to be further copied/distributed or hosted elsewhere without the express permission from Elsevier. 
NOT THE PUBLISHED VERSION; this is the author's final, peer-reviewed manuscript. The published version may be accessed by following the link in the citation at the bottom of the page.
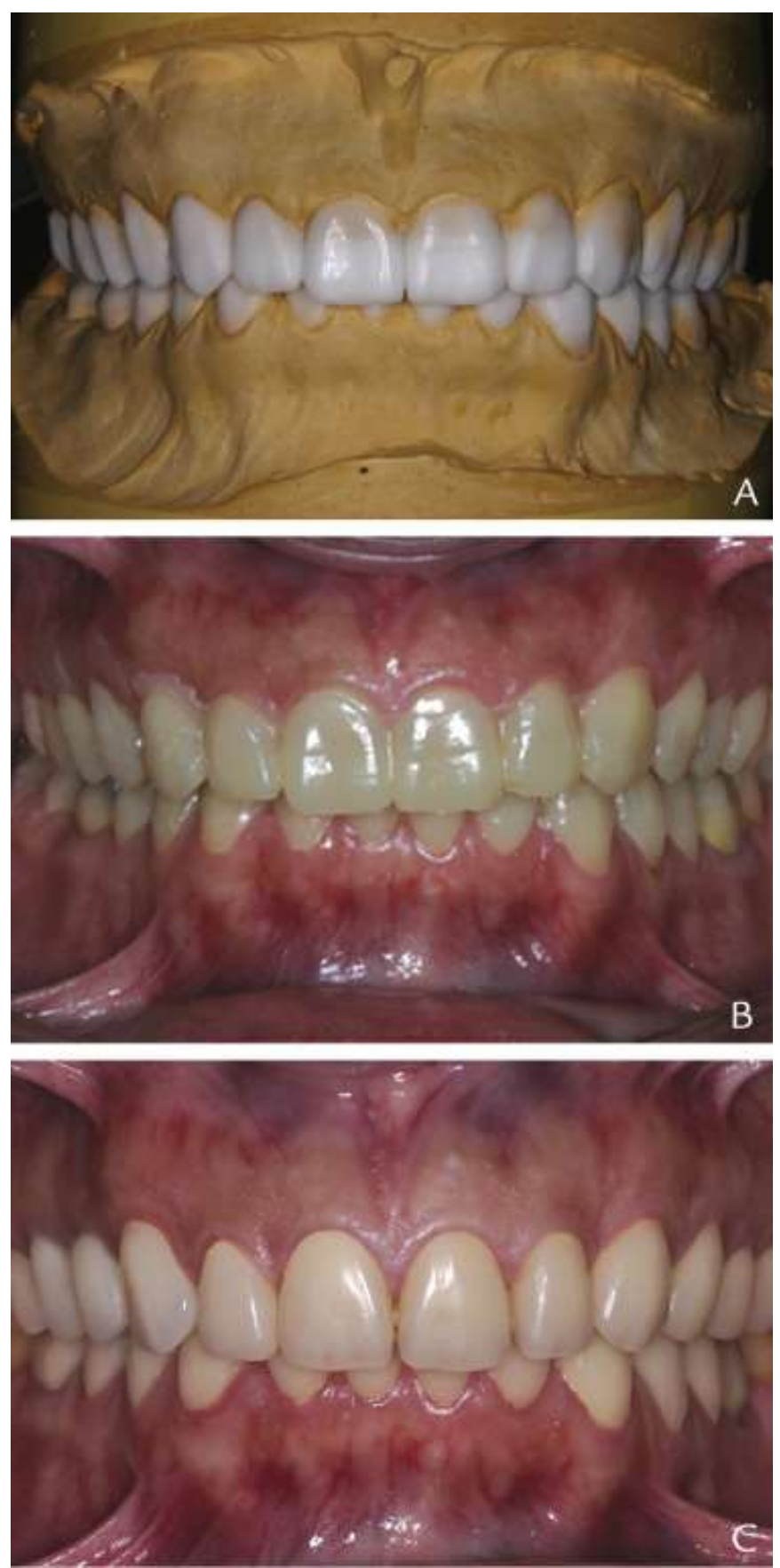

Figure 8. A, Diagnostic waxing at proposed occlusal vertical dimension. B, Intraoral evaluation of trial restorations from diagnostic waxing. C, Interim prostheses.

The problems identified were moderate dental wear, recurrent caries on several teeth, periapical pathosis on the mandibular first molars, inadequate tooth structure on the maxillary right second premolar, nonrestorable maxillary right first premolar and mandibular

Journal of Prosthetic Dentistry, Vol 117, No. 1 (January 2017): pg. 1-7. DOI. This article is @ Elsevier and permission has been granted for this version to appear in e-Publications@Marquette. Elsevier does not grant permission for this article to be further copied/distributed or hosted elsewhere without the express permission from Elsevier. 
left first molar, occlusal interferences, no anterior guidance in maximum intercuspation position, and uneven gingival display in an exaggerated smile (Fig. 6). The definitive diagnosis included worn dentition due to erosion and attrition, 9, 10, 11 and 12 caries, and occlusal instability. There was no periodontal pathosis, and her caries risk was high. ${ }^{13}$ The patient was characterized as category 2 relative to occlusal vertical dimension associated with a treatment plan ${ }^{14}$ and as PDI class IV for completely dentate patients. ${ }^{19}$ Treatment objectives were to control GERD, to manage caries by risk assessment, to maintain periodontal health, and to perform functional and esthetic restorations. Important treatment modifiers were GERD, bruxism, and the patient's esthetic demands. Possible options to restore teeth with poor prognosis were discussed, and the patient rejected 3-unit FDPs as definitive prostheses.

Nonrestorable teeth were extracted. At the maxillary right second premolar extraction site, a ridge preservation technique was performed with freeze-dried bone allograft (RegenerOss Allograft; Biomet 3i LLC) and resorbable collagen membrane (OsseoGuard; Biomet 3i LLC). After 6 months of healing, an implant was placed with the aid of a surgical guide (Replace Select RP; Nobel Biocare). At the mandibular left first molar extraction site, implant placement and grafting were performed simultaneously (Replace Select RP; Nobel Biocare). Teeth with inadequate tooth structure were restored with composite resin core foundation material (FluoroCore 2; Dentsply Intl) after RCT. The crowns of the maxillary anterior teeth were lengthened to improve the uneven gingival display. After 4 months of healing, the implants were loaded with interim prostheses, which were fabricated based on the diagnostic waxing and which established a mutually protected occlusion scheme (Fig. 8). Esthetics, function, oral hygiene, and soft tissue maturation were monitored for 6 months. Definitive impressions and a definitive cast mounting were made as described in patient 1. A custom-made zirconia abutment (NobelProcera Abutment Zirconia; Nobel Biocare) was fabricated for the maxillary implant, and a custom-made gold alloy abutment for the mandibular implant (Fig. 9). All teeth received lithium disilicate (IPS e.max Press; Ivoclar Vivadent AG) crowns, which were adhesively cemented (Calibra; Dentsply Intl). Layered zirconia crowns were fabricated on custom abutments and cemented with resin-modified glass ionomer cement (Fuji Plus, GC Corp) (Fig. 10). 

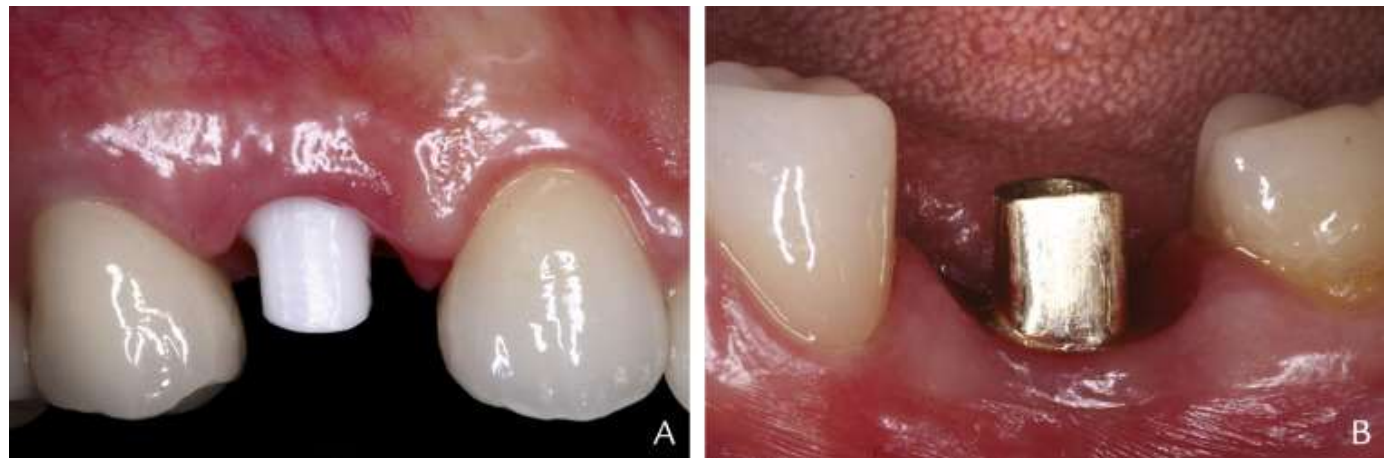

Figure 9. Implant custom abutments. A, Computer-aided designed and computeraided manufactured (CAD-CAM) custom zirconia abutment on implant at maxillary right first premolar site. B, Custom cast gold abutment on implant at mandibular left first molar site.
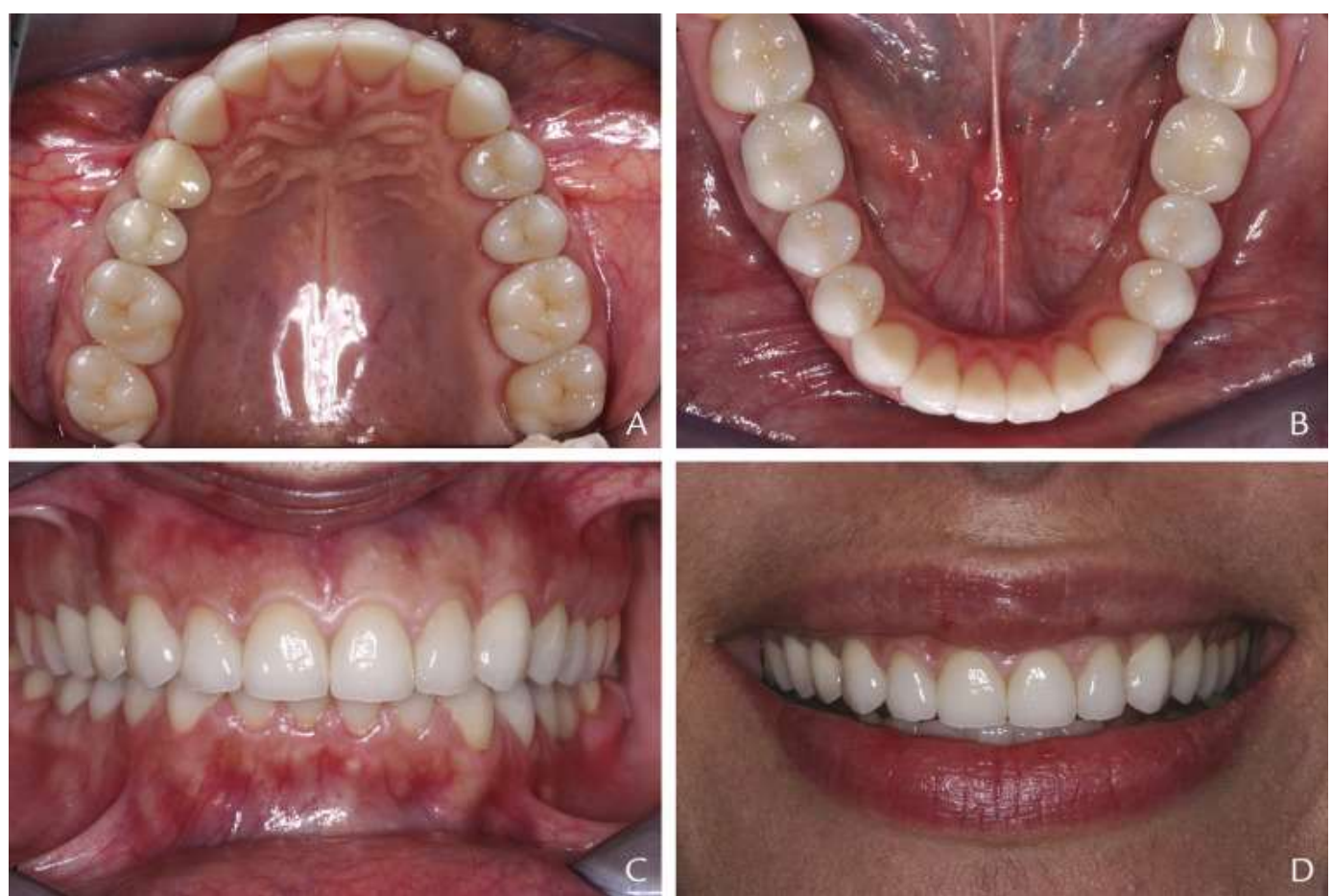

Figure 10. Inserted definitive prostheses. A, B, Occlusal views. C, Maximum intercuspation position frontal view. D, Exaggerated smile.

At the 1-week follow-up evaluation, the patient was satisfied with her new prostheses. A maxillary occlusal device was delivered at that time. The patient entered a 4-month recall maintenance program and has been followed for 2 years. The maintenance of oral and dental health were emphasized to improve the long-term prognosis. 
NOT THE PUBLISHED VERSION; this is the author's final, peer-reviewed manuscript. The published version may be accessed by following the link in the citation at the bottom of the page.

\section{Discussion}

Based on its cause, tooth wear is characterized as erosion, attrition, and abrasion. ${ }^{10}$ and 11 Erosion is further characterized as extrinsic or intrinsic based on the acid origin. ${ }^{12} \mathrm{~A}$ thorough review of medical history and clinical examination should reveal the exact cause, although synergy between factors may exist. ${ }^{9}$ In patient 1 , the following wear patterns were consistent with intrinsic erosion: wear on the occlusal surfaces of mandibular posterior teeth and on the lingual surfaces of maxillary posterior teeth, wear facets with a satiny finish and rounded edges, and the presence of amalgam islands. ${ }^{10,11}$ and 12 However, on the right mandibular canine and premolars, facets were located in areas of occlusal contact. They were flat, had sharp edges, and indicated attrition. In patient 2, anterior tooth wear patterns indicated intrinsic erosion, whereas posterior tooth wear patterns showed synergy between intrinsic erosion (GERD) and attrition (bruxism).10, 11 and 12

After the cause of wear is diagnosed, all systemic and local etiologic factors should be controlled before prosthodontic treatment. If dental erosion results in minor wear, teeth could be restored with direct composite resin restorations. ${ }^{20}$ If the loss of tooth structure is extensive, then indirect complete coverage restorations are indicated. Another issue when treating patients with GERD is the susceptibility of materials to a low-pH environment. Both resin-modified glass ionomer and resin cements have comparable acid resistance, which is higher than for water-based cements. ${ }^{21}$ Also, subgingival margin location prevents degradation of the tooth/restoration interface or exposure of the tooth surface to acids. ${ }^{22}$

\section{Summary}

This clinical report describes the diagnosis and treatment sequence of 2 patients with GERD who required complete mouth rehabilitation. Two different treatment approaches were followed. In patient 1 , no implants were used, and a root-resected mandibular molar served as an FDP abutment. In patient 2, implants and augmentation techniques were used, and every tooth/implant was restored with a single restoration. The use of contemporary ceramic 
materials resulted in improved esthetics. Both approaches offered viable solutions. A favorable long-term prognosis can be achieved by taking into account each patient's needs along with careful patient selection and an individualized maintenance program.

\section{References}

${ }^{1}$ N. Vakil, S.V. van Zanten, P. Kahrilas, J. Dent, R. Jones. The Montreal definition and classification of gastroesophageal reflux disease: a global evidence-based consensus. Am J Gastroenterol, 101 (2006), pp. 1900-1920

2M. Büchler. Gastroesophageal reflux disease (GERD): back to surgery? Karger, Basel (1997), pp. 22-24

${ }^{3}$ S.R. Bista, T.J. Barkoukis. Medical disorders impacted by obstructive sleep apnea. Dent Clin North Am, 56 (2012), pp. 373-386

${ }^{4}$ R.P. Barron, R.P. Carmichael, M.A. Marcon, G.K. Sandor. Dental erosion in gastroesophageal reflux disease. J Can Dent Assoc, 69 (2003), pp. 8489

${ }^{5}$ P. Moayyedi, A.T. Axon. Review article: gastro-oesophageal reflux diseasethe extent of the problem. Aliment Pharmacol Ther, 22 (suppl 1) (2005), pp. 11-19

6].A. Marsicano, P.G. de Moura-Grec, R.C. Bonato, C. Sales-Peres Mde, A. Sales-Peres, S.H. Sales-Peres. Gastroesophageal reflux, dental erosion, and halitosis in epidemiological surveys: a systematic review. Eur Journal Gastroenterol Hepatol, 25 (2013), pp. 135-141

${ }^{7}$ B.L. Gregory-Head, D.A. Curtis, L. Kim, J. Cello. Evaluation of dental erosion in patients with gastroesophageal reflux disease. J Prosthet Dent, 83 (2000), pp. 675-680

${ }^{8}$ D.A. Ali, R.S. Brown, L.O. Rodriguez, E.L. Moody, M.F. Nasr. Dental erosion caused by silent gastroesophageal reflux disease. J Am Dent Assoc, 133 (2002), pp. 734-737

${ }^{9}$ R.G. Verrett. Analyzing the etiology of an extremely worn dentition. J Prosthodont, 10 (2001), pp. 224-233

${ }^{10} \mathrm{~F}$. Spear. A patient with severe wear on the anterior teeth and minimal wear on the posterior teeth. J Am Dent Assoc, 139 (2008), pp. 1399-1403

${ }^{11} \mathrm{~F}$. Spear. A patient with severe wear on the posterior teeth and minimal wear on the anterior teeth. J Am Dent Assoc, 140 (2009), pp. 99-104

${ }^{12}$ D.A. Curtis, J. Jayanetti, R. Chu, M. Staninec. Decision-making in the management of the patient with dental erosion. J Calif Dent Assoc, 39 (2011), pp. 259-265

13J.D. Featherstone, S. Singh, D.A. Curtis. Caries risk assessment and management for the prosthodontic patient. J Prosthodont, 20 (2011), pp. 2-9

Journal of Prosthetic Dentistry, Vol 117, No. 1 (January 2017): pg. 1-7. DOI. This article is (c) Elsevier and permission has been granted for this version to appear in e-Publications@Marquette. Elsevier does not grant permission for this article to be further copied/distributed or hosted elsewhere without the express permission from Elsevier. 
NOT THE PUBLISHED VERSION; this is the author's final, peer-reviewed manuscript. The published version may be accessed by following the link in the citation at the bottom of the page.

${ }^{14} \mathrm{~K}$. A. Turner, D.M. Missirlian. Restoration of the extremely worn dentition. J Prosthet Dent, 52 (1984), pp. 467-474

${ }^{15}$ T.J. McGarry, A. Nimmo, J.F. Skiba, R.H. Ahlstrom, C.R. Smith, J.H. Koumjian, et al. Classification system for partial edentulism. J Prosthodont, 11 (2002), pp. 181-193

${ }^{16}$ C.H. Basten, W.F. Ammons Jr., R. Persson. Long-term evaluation of rootresected molars: a retrospective study. Int J Periodontics Restorative Dent, 16 (1996), pp. 206-219

${ }^{17}$ B.S. Vence. A systematic approach to full-mouth rehabilitation: clinical and laboratory guidelines. Quintessence, 24 (2001), pp. 78-92

${ }^{18} \mathrm{~J} . \mathrm{P}$. Okeson. Management of temporomandibular disorders and occlusion. (7th ed.)Mosby, St. Louis, MO (2013), p. 395

${ }^{19}$ T.J. McGarry, A. Nimmo, J.F. Skiba, R.H. Ahlstrom, C.R. Smith, J.H. Koumjian, et al. Classification system for the completely dentate patient. J Prosthodont, 13 (2004), pp. 73-82

${ }^{20} \mathrm{~K}$. Aziz, A.J. Ziebert, D. Cobb. Restoring erosion associated with gastroesophageal reflux using direct resins: case report. Oper Dent, 30 (2005), pp. 395-401

${ }^{21}$ F.I. Kuybulu, D. Gemalmaz, C.H. Pameijer, A. Yarat, T. Alcan. Erosion of luting cements exposed to acidic buffer solutions. Int J Prosthodont, 20 (2007), pp. 494-495

22]. Guo, G. Reside, L.F. Cooper. Full-mouth rehabilitation of a patient with gastroesophageal reflux disease: a clinical report. J Prosthodont, 20 (suppl 2) (2011), pp. S9-S13

Corresponding author: Dr Georgios Maroulakos, 415 E. Vine St, \#304, Milwaukee, WI 53212

Journal of Prosthetic Dentistry, Vol 117, No. 1 (January 2017): pg. 1-7. DOI. This article is @ Elsevier and permission has been granted for this version to appear in e-Publications@Marquette. Elsevier does not grant permission for this article to be further copied/distributed or hosted elsewhere without the express permission from Elsevier. 